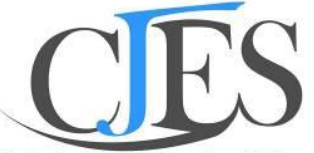

Cypriot Joumal of Educational Sciences

www.cjes.eu

\title{
High diploma students' perceptions of justice and its correlation with organisational commitment.
}

Fathi Shamma a ${ }^{1}$, The Arab Academic College for Education, P. O. box 114, Haifa area. https://orcid.org/00000001-8999-6083

Reem Al-Zu'bi ${ }^{\text {b }}$ Al-al Bayt University, P. O. Box 130040, Mafraq, Jordan. https://orcid.org/0000-0002-7464-0815

\section{Suggested Citation:}

Fathi Shamma, Reem Al-Zu'bi (2020). High diploma students' perceptions of justice and its correlation with organisational commitment. Cypriot Journal of Educational Science. 15(4), 854 -869. DOI:

10.18844/cjes.v\%vi\%i.5064

Received from April 1, 2020; revised from June 5, 2020; accepted from August 25, 2020.

(C2020 Birlesik Dunya Yenilik Arastirma ve Yayincilik Merkezi. All rights reserved.

\begin{abstract}
This study reveals the correlations between high diploma student's perceptions of the level of organisational justice exhibited by Jordanian school principals and their own level of organisational commitment. To achieve these objectives, the researchers employed a descriptive correlation design. A 44-item questionnaire comprising four fields was administered to a sample of (354) high diploma students working as teachers in (15) public schools. The results show there is evidence of perceived justice and a high level of commitment among teachers; additionally, it identified a strong connection between teachers' commitment and all aspects of organisational justice. These findings have implications for Jordanian school administration; accordingly, the researchers propose relevant recommendations for further investigation.
\end{abstract}

Keywords: organisational justice (OJ); organisational commitment (OC); high diploma.

\footnotetext{
$1_{*}$ ADDRESS FOR CORRESPONDENCE: Fathi Shamma ,The Arab Academic College, , P. O. box 114, Haifa area.

E-mail address: fsh1308@gmail.com / Tel.: +972059572258.
} 
Fathi Shamma, Reem Al-Zu'bi (2020). High diploma students' perceptions of justice and its correlation with organisational commitment.. Cypriot Journal of Educational Science. 15(4), 854 -869. DOI: 10.18844/cjes.v\%vi\%i.5064

\section{Introduction}

The bond that exists between individuals in organisations based on their hierarchy can bring about justice. Employees' awareness of justice is reflected in positive attitudes to work and dedication to their duties in the organisation. Hamid (2003) defines organisational justice as the level at which workers feel fairly treated. Employers exhibit an outstanding work ethic in an environment in which they observe fairness. Amongst the most critical educational changes with respect to administrative processes and human capital is the introduction of organisational justice (OJ). This encompasses how employees behave, their performance at work, the quality of their output, and other essential factors that can have a positive or negative effect on educational administration (Greenberg, 1987; Imamoglu, Ince, Turkcan \& Birsen, 2019).

Justice is a complex and multidimensional concept. An image of justice is dependent on an institution's point of view. This results in different stereotypical and behavioural outcomes, which include trusting the organisation, displaying greater organisational commitment, exhibiting loyalty to the organisation, and actively participating in its affairs (Collquitt, Canlun, Wesson \& Porter, 2001). Most studies on organisational justice agree that employees categorize a sense of justice in accordance with three basic orientations, namely;

1. First, organisational outputs such as bonuses, salaries, and workload. According to Till and Karren (2011), employees compare their outcomes with other employees in similar organisations or institutions.

2. Second, procedures and laws that direct the distribution of outputs such as bonuses, workload, and salaries. Thibaut and Walker (1975) believe that procedural justice is enhanced when an organisation places greater emphasis on procedures and laws.

3. Finally, personal treatment affects an employee's decisions if it is focused on respect and appreciation (Bies \& Moag, 1987; Aranki, Suifan \& Swies, 2019; Salehi, Sima \& Fahimi, 2020).

\subsection{Distributive Justice (DJ)}

Distributive justice affects the working environment as it focuses on aspects of research and study in relation to functional justice. This approach has been acknowledged as important by many researchers, scientists, and decision-makers working in multiple fields of study and institutions (Greenberg, 1987).

\section{2 procedural justice (PJ)}

Justice is procedural when managers and top management in institutions make resource allocation decisions by ensuring that organisations use methods and procedures to assess their employees' performance and that all employees are treated fairly (Tepper \& Taylor, 2003). It thus bases the level at which fairness is felt by employees in terms of how they are treated by their principals. This includes a show of respect, trust, and cooperation by top administrative personnel to regular workers (Fahdawi \& Al-Qatawneh, 2007, Terzi, Dulker, Altin, Celik, Dalkiran, Yulcu, Tekin \& Deniz, 2017).

\subsection{Interactive Justice (IJ)}

Rego and Chuna (2010) also explored how managers of organisations relate to their employees. They found that managers treat their employees according to how credible and respectful they can be or the quality of treatment the employee receives from organisational decision-makers.

Justice relates strongly to the concept of organisational commitment, which creates an environment in which to achieve an institution's goals, strengthen creativity and reliability among employees, and 
enhance trust between the different poles of the institution. Researchers have concluded that justice and commitment are inseparable as commitment cannot be successful if justice is absent (Fahdawi \& Al-Qatawneh, 2004; Al-Ubaidi, 2012; McFee, 2016).

Al-Wazzan (2006) defines organisational commitment as an individual's psychological willingness and internal desire to work in the institution. This is characterised by an obligation to do their utmost to serve the interests of the institution and remain affiliated to it. Harris (2009) defines organisational commitment as the correlation that exists between employees in one organisation. Conversely, Abu Samaan (2015) perceives it as more of a loyalty reward issued to employees as a sign of appreciation and an incentive for them to do more for the organisation. It is an inducement that is highly effective in fulfilling the aims and goals of the institution. For instance, it encourages employees to work hard to ensure the success of the organisation with respect to its objectives and values. Therefore, staff members believe in achieving success in accordance with standards acceptable within the institution.

The dimensions central to organisational commitment are as follows:

1. Emotional Commitment: This is a measure of how satisfied employees are with their organisations, which impacts their willingness to continue working and to be productive. Principals who instill in their employees a sense of belonging to the organisation encourage them to do more to ensure its growth and survival (Bolon, 1997; Mowday, Steers \& Porter, 1979).

2. Continued Commitment: In this form of commitment, employees foresee leaving the institution as an option that does not favor them in the long term.

3. Normative Commitment: Here, employees see themselves as important in their workplace and thus feel the need to continue working towards organisational growth. Consequently, employees have reasons to remain in the organisation (Meyer \& Allen, 1997).

Dodman, Rahim and Zadeh, (2014); Ting (2014); and Srinivasan and Selvi (2016) categorized the importance of organisational commitment into the following levels:

1. National Level: the organisational commitment of employees increases the efficiency and effectiveness of an organisation.

2. Social Level: Promoting interactions between employees of different levels can lead to better bonding; this increases employee's happiness and job satisfaction, which is key to organisational development.

3. Organisational Level: This reduces negative phenomena in an organisation such as delays in work, absence, and job leakage. This in turn leads to increased productivity and improves quality.

4. Individual Level: At this level, employees focus on attaining job security and economic reliability while still maintaining a high level of job satisfaction in the organisation.

\section{Significance of the Study \& Statement of the Problem}

The success and progress of an organisation is based upon employees' sense of justice which will be reflected in their loyalty and commitment. The current research identifies the extent of commitment among employees to the educational organisation. Very few Jordanian studies have tackled this topic; therefore, the current study will contribute to supplementing the existing body of research. The results and subsequent recommendations will serve as a reference for educational leaders when setting their 
Fathi Shamma, Reem Al-Zu'bi (2020). High diploma students' perceptions of justice and its correlation with organisational commitment.. Cypriot Journal of Educational Science. 15(4), 854 -869. DOI: 10.18844/cjes.v\%vi\%i.5064

plans, changing existing plans, or diagnosing the strengths and weaknesses of their management style. The following are the sub research questions addressed in the study:

1. What do high diploma students perceive the level of justice to be in Jordanian schools?

2. What level of organisational commitment do high diploma students have?

3 What is the correlation between the level of justice perceived by high diploma students in Jordanian schools and their level of commitment?

\section{Literature review}

Several extensive studies have investigated the correlation between justice in organisations and levels of commitment in the educational environment.

For instance, Jameel, Mahmoud and Jwmaa (2020) examined the correlation between organisational justice and organisational commitment in secondary schools. Their sample comprised (98) teachers working in eight public secondary schools. They found that organisational justice has three dimensions; distributive, procedural, and interactional justice. The authors utilized these dimensions to measure justice and determine the level of commitment among teachers. They distributed an organisational commitment questionnaire to teachers, the responses to which were analysed using regression analysis and Pearson's correlation coefficient. The results indicated that the correlation between justice and commitment within an organisation was significantly positive.

Edeh and Joy (2019) employed a survey design to investigate the correlation between justice and the commitment of teachers at Nigerian private schools. The sample comprised twenty (20) randomly selected private secondary schools in Bayelsa State. From these, they surveyed (183) teachers using Krejcie and Morgan sample size determination tables. The results revealed that organisational justice was positively associated with the commitment of the staff.

Peretomode's research (2018) examined the overall commitment of public high school teachers in Edo State and their level of commitment across each of the three dimensions of commitment. The results showed that the overall level of commitment of teaching staff to the school was extremely high and stronger among female teachers than male teachers. Furthermore, teachers' commitment to the school was high across all three dimensions of organisational commitment.

Goyker's study (2018) explored the perceptions of high school teachers regarding their work and their commitment level. Most of the teachers said their school was the best and they were proud to work there. Indeed, they would prefer to continue working there even if they were given the chance to work elsewhere. The teachers further indicated that they were proud to be teachers and this drove their commitment to their work.

Shamma (2018) explored the level of commitment among 230 male and female teachers working in Palestinian Arab schools. The results showed there was an extremely high level of commitment among these teachers.

Demir (2016) employed a meta-analysis to investigate the correlation between schoolteachers' perceptions of organisational justice, commitment, and job satisfaction. To reduce perceived inaccessibility bias, this study followed the inductive approach of published and unpublished research 
work. Several of the research reports reviewed found that teachers' overall perception of justice was positively correlated with organisational engagement.

Another study conducted by Melhem and Al-Aqra (2018) highlighted the impact of several variables on organisational justice at female secondary schools in Qalqilya-Gaza. The results showed there was no significant distinction between teachers' responses to questions on the level of justice. This was assessed for two variables (functional grade, place of residence of the teacher) on all dimensions, and the total score. For two other variables (social status, years of work in a school), there was a significant distinction between teacher's responses towards the level of justice and marital status on all dimensions. The differences attributed to years of work in the school were on the distributive justice dimension for the category 'more than 10 years of experience'.

Other research studies have revealed different results, such as Chevalier's (2019) research which employed descriptive analysis to analyse the impact of organisational justice on the commitment of teachers working in public secondary schools in Cameroon. The results indicated that there was a low level of fairness in these schools and this affected teachers' commitment to work.

Research by Al-Sbei (2019), Hasaani (2015), and Al-Harahshah (2012) indicated that the degree to which organisational justice was practiced in schools from the teachers' perspective was medium. Therefore, the level of commitment among teachers was also medium. Safdar and Liu (2019) and Jang, Woong Lee and Kwon (2019) conducted research to examine the correlation between justice and the commitment of staff to their organisation. The results revealed clear correlations at all levels. Despite the intensive research conducted on the level of organisational justice and its correlation with organisational commitment, only a small amount of research has been conducted in Jordanian schools. The present study therefore narrows the existing gap in the literature by focusing on Jordanian schools.

\section{Method}

A quantitative approach was adopted as this was suitable for addressing the purpose of the study. The population comprised all (462) male and female diploma students at AABU working as teachers in public schools for the academic year 2019-2020. A random sample of 331 male and female diploma students at $A A B U$ was then selected to participate in the study. Based on a thorough review of the literature, the researchers designed the research instrument following Shamma and Shorman (2018). The final form of the questionnaire comprised four demographic questions and 44 items covering students' perceptions of organisational justice. These were divided into four primary areas: distributive justice (eight items), procedural justice (nine items), interactive justice (nine items), and organisational commitment (18 items) (see the appendix). The validity of the questionnaire was established by a jury of (five) educational professors and four classroom teachers; following their comments, the researchers deleted (seven) items and one field. They then conducted a test-retest on thirty diploma students to establish the reliability of the questionnaire. These students were then excluded from the sample. There was a twenty-two day interval between the two administrations of the questionnaire. To analyse the data, the researchers extracted the means and standard deviations for the fields and the tool as a whole, and conducted a Pearson's correlation coefficient analysis to reveal the relationship between the degree 
Fathi Shamma, Reem Al-Zu'bi (2020). High diploma students' perceptions of justice and its correlation with organisational commitment.. Cypriot Journal of Educational Science. 15(4), 854 -869. DOI: 10.18844/cjes.v\%vi\%i.5064

of organisational justice and organisational commitment. Table (1) presents the reliability coefficients for the tool.

Table 1. Reliability coefficients for the tool

\begin{tabular}{ccc}
\hline Field & Internal consistency & Repetition reliability \\
\hline DJ & 0.83 & 0.93 \\
PJ & 0.87 & 0.94 \\
IJ & 0.92 & 0.94 \\
Total OJ & 0.94 & 0.97 \\
OC & 0.76 & 0.94 \\
\hline
\end{tabular}

Table 1 shows that, in terms of repetition reliability, the coefficients for the organisational justice fields ranged between (0.93-0.94), and were (0.97) for organisational justice as a total score. The value of the coefficient for the total organisation commitment field was (0.94). Regarding internal consistency, the coefficients for the organisational justice fields ranged between ( 0.83 and 0.94$)$ while the value for organisational commitment was (0.76). These results indicate acceptable levels of reliability.

\section{Results \& Discussion}

\subsection{First Research Question}

What do high diploma students perceive the level of justice to be in Jordanian schools? The results are presented in Table 2:

Table 2. Means and standard deviations of the fields

\begin{tabular}{llllll}
\hline \multirow{2}{*}{ Item } & \multirow{2}{*}{ Research Area } & Mea & SD & Degree & Rank \\
\hline 3 & IJ & 4.10 & .770 & High & 1 \\
2 & PJ & 3.80 & .789 & High & 2 \\
1 & DJ & 3.74 & .783 & High & 3 \\
& OJ & 3.85 & .752 & High & \\
\hline
\end{tabular}

Table 2 shows that the means of the research fields are all at a top-level. The interactive justice field has the highest mean of (4.10), followed by the field of procedural justice with a mean of (3.80). The field of distributive justice has a mean of (3.74). The researchers attribute this result to the fact that most modern schools endeavor to build strong ties with their staff using modern leadership theories. It illustrates principals' awareness of the role of social interaction, their appreciation of effort, their ability to identify and address the needs of staff, and the implementation of an accessible-door policy . All these have contributed significantly to the development of an interactive justice system in the school as principals are cognizant of the fact that organisational justice within schools affects teachers at a high level. This result is in agreement with studies by Fahdawi and Qatarneh (2004), Demir (2016), McFee, (2016), Goyker (2018), Shamma (2018), Petermode (2018), Edeh and Joy (2019), and Jameel et al. (2020). However, it diverges from the results obtained by Al-Sbei (2019), Melhem and Al-Aqra (2018), Hassani (2015), and Al-Harahshah (2012) who found the correlation between the level of justice and 
commitment in an organisation to be at a medium level. The results also differed from those of Chevalier's study (2019), which indicated that justice in public secondary schools was at a low level.

Table 3. Means and standard deviations for the distributive justice field

\begin{tabular}{|c|c|c|c|c|c|}
\hline Item & Area & Mean & SD & Degree & Rank \\
\hline 1 & $\begin{array}{l}\text { All tasks are fairly allocated to } \\
\text { all teachers. }\end{array}$ & 4.33 & 0.628 & High & 5 \\
\hline 2 & $\begin{array}{l}\text { My work responsibility is taken } \\
\text { into consideration by the } \\
\text { school authorities in } \\
\text { determining my reward }\end{array}$ & 4.56 & 0.575 & High & 1 \\
\hline 3 & $\begin{array}{l}\text { Promotion in the school is done } \\
\text { fairly and is open to every } \\
\text { employer }\end{array}$ & 4.24 & 0.646 & High & 6 \\
\hline 4 & $\begin{array}{l}\text { The incentives for teachers are } \\
\text { allocated fairly and } \\
\text { transparently. }\end{array}$ & 4.24 & 0.620 & High & 4 \\
\hline 5 & $\begin{array}{l}\text { All teachers are given fair } \\
\text { opportunities to represent the } \\
\text { school in inter-school activities. }\end{array}$ & 4.53 & 0.562 & High & 3 \\
\hline 6 & $\begin{array}{l}\text { Weekly programs set by the } \\
\text { principal are done with } \\
\text { consideration }\end{array}$ & 4.03 & 0.926 & High & 7 \\
\hline 7 & $\begin{array}{l}\text { The principal assigns the duties } \\
\text { to teachers based on their } \\
\text { specialty }\end{array}$ & 4.02 & 0.823 & High & 8 \\
\hline \multirow[t]{2}{*}{8} & $\begin{array}{l}\text { The principal involves teachers } \\
\text { from different faculties }\end{array}$ & 4.54 & 0.571 & High & 2 \\
\hline & Distributive Justice & 4.34 & 0.793 & High & \\
\hline
\end{tabular}

Table 3 shows that item (2), My work responsibility is taken into consideration by the school authorities in determining my reward has the highest mean of 4.56 with a standard deviation of 0.575 . By contrast, item (7), The principal assigns the duties to teachers based on their specialty, has the lowest mean of 4.02 with a standard deviation of (.823). The table shows total distributive organisational justice to have a mean value of 4.34 and a standard deviation of .793 . The high degree of distributive 
Fathi Shamma, Reem Al-Zu'bi (2020). High diploma students' perceptions of justice and its correlation with organisational commitment.. Cypriot Journal of Educational Science. 15(4), 854 -869. DOI: 10.18844/cjes.v\%vi\%i.5064

organisational justice suggests that principals understand the value of respecting their subordinates and the impact of teacher's involvement and interaction in achieving the visions of the school.

Table 4. Means and standard deviations for the procedural justice field

\begin{tabular}{|c|c|c|c|c|c|}
\hline Item & Area & Mean & SD & Degree & Rank \\
\hline 1 & $\begin{array}{l}\text { The teachers have the freedom to } \\
\text { explain themselves if judged } \\
\text { negatively. }\end{array}$ & 4.60 & 0.600 & High & 2 \\
\hline 2 & $\begin{array}{l}\text { The principal provides transparent } \\
\text { and fair information to teachers }\end{array}$ & 4.13 & 0.753 & High & 9 \\
\hline 3 & $\begin{array}{l}\text { The principal involves all teachers in } \\
\text { the decision making of the school. }\end{array}$ & 4.61 & 0.677 & High & 1 \\
\hline 4 & $\begin{array}{l}\text { Periodic evaluation of teachers } \\
\text { during the academic year is } \\
\text { performed transparently. }\end{array}$ & 4.55 & 0.660 & High & 3 \\
\hline 5 & $\begin{array}{l}\text { Decisions made by the principal } \\
\text { regarding my job were done with } \\
\text { clarity and accuracy. }\end{array}$ & 4.24 & 0.720 & High & 8 \\
\hline 6 & $\begin{array}{l}\text { In the event of teachers notifying } \\
\text { abuse, the principal shall take fair } \\
\text { measures. }\end{array}$ & 4.29 & 0.760 & High & 7 \\
\hline 7 & $\begin{array}{l}\text { The principal clearly explains all } \\
\text { teachers' administrative decisions. }\end{array}$ & 4.54 & 0.627 & High & 4 \\
\hline 8 & $\begin{array}{l}\text { The principal is receptive to } \\
\text { suggestions for efficiency } \\
\text { enhancements. }\end{array}$ & 4.54 & 0.605 & High & 5 \\
\hline 9 & $\begin{array}{l}\text { Teachers are entitled to express their } \\
\text { opinions on the school } \\
\text { administration's decisions. }\end{array}$ & 4.48 & 0.721 & High & 6 \\
\hline & Procedural justice & 4.43 & 0.875 & High & \\
\hline
\end{tabular}

Table 4 shows that the means for this field varied between 4.13-4.61, which is high. Item (3), The principal involves all teachers in the decision making of the school, ranked highest with a mean of 4.61 and a standard deviation of .667. Item (2), The principal provides transparent and fair information to teachers, has the lowest mean value of 4.13 with a standard deviation of .753 . The table also shows that the level of procedural justice in the school is high. indicating that the principal adheres to the principle of openness and the rights of teachers to understand the decisions and encourages them to interact respectively, particularly regarding any decision taken against them. 
Fathi Shamma, Reem Al-Zu'bi (2020). High diploma students' perceptions of justice and its correlation with organisational commitment.. Cypriot Journal of Educational Science. 15(4), 854 -869. DOI: 10.18844/cjes.v\%vi\%i.5064

Table 5. Means and standard deviations for the interactive justice field

\begin{tabular}{|c|c|c|c|c|c|}
\hline Item & Area & Mean & SD & Degree & Rank \\
\hline 1 & $\begin{array}{l}\text { The school principal treats } \\
\text { teachers fairly. }\end{array}$ & 4.57 & 0.580 & High & 1 \\
\hline 2 & $\begin{array}{l}\text { The principal respects and } \\
\text { appreciates teachers. }\end{array}$ & 4.32 & 0.813 & High & 4 \\
\hline 3 & $\begin{array}{l}\text { The principal allows the } \\
\text { teachers to engage equally } \\
\text { and critically in } \\
\text { administrative decision- } \\
\text { making. }\end{array}$ & 4.33 & 0.618 & High & 3 \\
\hline 4 & $\begin{array}{l}\text { The principal is actively } \\
\text { involved and interested in } \\
\text { decisions that are pertinent } \\
\text { to my work. }\end{array}$ & 4.31 & 0.849 & High & 5 \\
\hline 5 & $\begin{array}{l}\text { The principal encourages } \\
\text { teachers' } \\
\text { initiatives. }\end{array}$ & 4.22 & 0.890 & High & 7 \\
\hline 6 & $\begin{array}{l}\text { The principal } r \text { keenly } \\
\text { encourages a spirit of } \\
\text { cooperation } \\
\text { teachers. }\end{array}$ & 4.42 & 0.620 & High & 2 \\
\hline 7 & $\begin{array}{l}\text { The principal notifies the } \\
\text { teachers promptly on the } \\
\text { implementation process for } \\
\text { official activities. }\end{array}$ & 4.28 & 0.624 & High & 6 \\
\hline 8 & $\begin{array}{l}\text { Teachers are involved in the } \\
\text { social activities of the school } \\
\text { without favoritism. }\end{array}$ & 4.19 & 0.919 & High & 8 \\
\hline \multirow[t]{2}{*}{9} & $\begin{array}{l}\text { Teacher's social and } \\
\text { personal welfare is of } \\
\text { concern to the principal. }\end{array}$ & 4.18 & 0.949 & High & 9 \\
\hline & Interactive Justice & 4.31 & 0.870 & High & \\
\hline
\end{tabular}

Table 5 shows that the means for this field are high and range between (4.18-4.57). Item (1), the school principal treats teachers fairly, ranks highest with a mean of (4.57) and a standard deviation of .580. Item (9), Teacher's social and personal welfare concerns the principal, has a mean of (4.18) and a standard deviation of (.949). This result shows that interactive justice within organisations is high. These 
Fathi Shamma, Reem Al-Zu'bi (2020). High diploma students' perceptions of justice and its correlation with organisational commitment.. Cypriot Journal of Educational Science. 15(4), 854 -869. DOI: 10.18844/cjes.v\%vi\%i.5064

results are consistent with those of Demir (2016), Petermode (2018), Goyker (2018), and Jameel et al. (2020).

\subsection{Second Research Question}

What level of organisational commitment do high diploma students have? The results are presented in Table 6.

Table 6. Means and Standard Deviations for the Organisational Commitment Field

\begin{tabular}{|c|c|c|c|c|c|}
\hline Item & Area & $\begin{array}{l}\text { Mea } \\
\mathrm{n}\end{array}$ & SD & $\begin{array}{l}\text { Degre } \\
\mathrm{e}\end{array}$ & Rank \\
\hline 1 & $\begin{array}{l}\text { I advise parents to enroll their kids in } \\
\text { the school. }\end{array}$ & 4.28 & 0.792 & $\begin{array}{l}\text { Very } \\
\text { High }\end{array}$ & 9 \\
\hline 2 & $\begin{array}{l}\text { I am actively involved in all school } \\
\text { activities. }\end{array}$ & 4.28 & 0.803 & $\begin{array}{l}\text { Very } \\
\text { High }\end{array}$ & 0 \\
\hline 3 & $\begin{array}{l}\text { My school motivates me to do } \\
\text { better by increasing my pay. }\end{array}$ & 4.23 & 0.848 & $\begin{array}{l}\text { Very } \\
\text { High }\end{array}$ & $4^{1}$ \\
\hline 4 & $\begin{array}{l}\text { The school's reputation is of interest } \\
\text { to me. }\end{array}$ & 4.72 & 0.572 & $\begin{array}{l}\text { Very } \\
\text { High }\end{array}$ & 1 \\
\hline 5 & $\begin{array}{l}\text { Until I retire, I am willing to continue } \\
\text { working at school. }\end{array}$ & 4.15 & 0.675 & High & $8^{1}$ \\
\hline 6 & I never miss a day at school. & 4.58 & 0.572 & $\begin{array}{l}\text { Very } \\
\text { High }\end{array}$ & 2 \\
\hline 7 & $\begin{array}{l}\text { My interests do not interfere with } \\
\text { the public interest of the school. }\end{array}$ & 4.31 & 0.746 & $\begin{array}{l}\text { Very } \\
\text { High }\end{array}$ & 4 \\
\hline 8 & I am proud to work at my school. & 4.31 & 0.782 & $\begin{array}{l}\text { Very } \\
\text { High }\end{array}$ & 5 \\
\hline 9 & $\begin{array}{l}\text { I am up to date with the activities of } \\
\text { the school's administration and its } \\
\text { organisational affairs. }\end{array}$ & 4.17 & 0.824 & $\begin{array}{l}\text { Very } \\
\text { High }\end{array}$ & 3 \\
\hline 10 & $\begin{array}{l}\text { I go beyond the school's } \\
\text { expectations to achieve its aims and } \\
\text { objectives. }\end{array}$ & 4.30 & 0.702 & $\begin{array}{l}\text { Very } \\
\text { High }\end{array}$ & 7 \\
\hline 11 & I can work extra hours at school. & 4.01 & 0.974 & $\begin{array}{l}\text { Very } \\
\text { High }\end{array}$ & $6^{1}$ \\
\hline 12 & $\begin{array}{l}\text { I readily perform the duties assigned } \\
\text { to me in school. }\end{array}$ & 4.30 & 0.702 & $\begin{array}{l}\text { Very } \\
\text { High }\end{array}$ & 8 \\
\hline 13 & $\begin{array}{l}\text { I can advise someone to work at my } \\
\text { school. }\end{array}$ & 4.28 & 0.807 & $\begin{array}{l}\text { Very } \\
\text { High }\end{array}$ & $1^{1}$ \\
\hline 14 & $\begin{array}{l}\text { I keep up to date with recent } \\
\text { developments to ensure that the } \\
\text { school is also kept up to date. }\end{array}$ & 4.41 & 0.712 & $\begin{array}{l}\text { Very } \\
\text { High }\end{array}$ & 6 \\
\hline 15 & $\begin{array}{l}\text { Fair organisational treatment makes } \\
\text { me work towards achieving the } \\
\text { school's aims and objectives. }\end{array}$ & 4.24 & 0.646 & $\begin{array}{l}\text { Very } \\
\text { High }\end{array}$ & $7^{1}$ \\
\hline 16 & I make use of my time efficiently. & 4.23 & 0.713 & $\begin{array}{l}\text { Very } \\
\text { High }\end{array}$ & $2^{1}$ \\
\hline 17 & $\begin{array}{l}\text { Until I retire, I am willing to continue } \\
\text { working at school. }\end{array}$ & 4.12 & 0.965 & $\begin{array}{l}\text { Very } \\
\text { High }\end{array}$ & $5^{1}$ \\
\hline
\end{tabular}


Fathi Shamma, Reem Al-Zu'bi (2020). High diploma students' perceptions of justice and its correlation with organisational commitment.. Cypriot Journal of Educational Science. 15(4), 854 -869. DOI: 10.18844/cjes.v\%vi\%i.5064

\begin{tabular}{|c|c|c|c|c|}
\hline 18 & $\begin{array}{l}\text { I carry out my administrative duties } \\
\text { based on a cordial relationship. }\end{array}$ & 4.36 & 0.562 & $\begin{array}{l}\text { Very } \\
\text { High }\end{array}$ \\
\hline & Commitment to the organisation & 4.22 & 0.571 & High \\
\hline
\end{tabular}

Table 6 shows the top means for the organisational commitment field, which range from (4.01 to 4.72). Item (4), The school's reputation is of interest to me, has the highest mean value of (4.61) with a standard deviation of (5.72). Item (11), I can work extra hours at school, has the lowest mean value of 4.01 with a standard deviation of .974. The researchers attribute this result to teachers' beliefs in fair procedures and open decisions. The employees are thus effective in productively and respectfully carrying out the tasks assigned to them to achieve the objectives and vision of their institutions. These results are consistent with those of Srinivasan and Selvi (2016), Peretomode (2018), Goyker (2018), and Jameel et al. (2020).

\section{3 Third Research Question}

What is the correlation between the level of organisational justice perceived by high diploma students and their level of commitment? Table 7 presents the Pearson correlation coefficients that show the correlations between the perceived level of organisational justice exhibited by the principals of Jordanian schools and the level of commitment among teachers.

Table 7. Pearson correlation coefficients for distributive justice, procedural justice, interactive justice, organisational commitment, and total organisational justice

\begin{tabular}{|c|c|c|c|c|c|c|}
\hline & & DJ & PJ & IJ & OC & $\begin{array}{l}\text { Total } \\
\text { OJ }\end{array}$ \\
\hline DJ & $\begin{array}{l}\text { Pearson } \\
\text { coefficient }\end{array}$ & 1 & & & & \\
\hline PJ & $\begin{array}{l}\text { Pearson } \\
\text { coefficient }\end{array}$ & $876^{* *}$. & 1 & & & \\
\hline IJ & $\begin{array}{l}\text { Pearson } \\
\text { coefficient }\end{array}$ & $835^{* *}$. & $3^{* * .88}$ & 1 & & \\
\hline OC & $\begin{array}{l}\text { Pearson } \\
\text { coefficient }\end{array}$ & $663^{* *}$. & $1^{* * .70}$ & $* * .702$ & 1 & \\
\hline Total OJ & $\begin{array}{l}\text { Pearson } \\
\text { coefficient }\end{array}$ & $941^{* *}$. & $8^{* * .95}$ & $* * .942$ & $* * .720$ & 1 \\
\hline
\end{tabular}

Table 7 shows that the correlations between teachers' organisational commitment and the fields of justice were positive and significant at $\alpha=0.05$. These results are consistent with those of Jameel et al. (2020); Edeh and Joy (2019; Jang et al. (2019); Safdar and Liu (2019); Petermode, 2018; and Shamma, 2018, all of whom identified a significant positive correlation between organisational justice and organisational commitment within schools.

\section{Conclusion \& Recommendations}

The findings of this study revealed that the correlation between perceived justice in Jordanian schools and the commitment of teachers is significant and positive. These results show that principals are aware 
of the role played by a fair organisational system in improving the commitment of teachers towards achieving the goals and objectives of the school. It also means that the organisational commitment of teachers increases in parallel with their perception of organisational justice. Consequently, teachers will commit to perform the tasks assigned to them effectively and respectfully. Based on the findings, the researchers recommend continually encouraging teachers to expend new energies by taking on the practical responsibility of setting and defining the future vision of schools. This will make them become more loyal and committed to the organisation. The findings also highlight the importance of holding ongoing discussions with direct officials of organisations regarding teachers' work problems and their views on their practice, primarily through the open-door policy. Further research using different variables and in a unique environment is needed to build on our current knowledge of justice in organisations and the corresponding commitment of workers.

\section{References}

Abu Samaan, M. (2015). The determinants of organizational justice and its correlation to the behavior of organizational citizenship from the viewpoint of police officers in the Gaza Strip. Master Thesis. [AlJamia Al-islamiah]: Gaza. Retrieved from https://iugspace.iugaza.edu.ps/handle/20.500.12358/17241

Al-Harahshah, M. (2012). The Degree of the sense of organizational justice by employees in the directorate of education in Mafraq Governorate. [Majalat Jamieat Al-Malik Suo'd lil-Eulum Al- TarbawiaH wa Al-Dirasat Al-'Iislamia], 1(40), 47-71. Retrieved from https://platform.almanhal.com/Files/2/76939

Al-Ubaidi, N. (2012). The impact of Organizational Justice and its Relation to Organizational Commitment: a field study at the ministry of higher education and scientific research. [. Majalat Tikrit Lil-Ulum Al-'Iidariat wa Al-Iqtisadia], 8(24). Retrieved from https://www.iasj.net/iasj?func=article\&aId=32445

Al-Wazzan, Khalid. (2006). The organizational climate and its relationship to organizational commitment. Master's Thesis, Naif Arab University for Security Sciences: Bahrain.

Aranki, D., Suifan, T., \& Sweis, R. (2019). The relationship between organizational culture and organizational commitment. Modern Applied Science, 13(4), 137. Retrieved from https://www.researchgate.net/publication/332107341_The_Correlation _between_Organizational_Culture_and_Organizational_Commitment

Bies, B., \& Shapiro, L. (1987). Interactional fairness judgments: the influence of causal accounts. Social Justice Research, 1(2), 188-218. Retrieved from https://link.springer.com/article/10.1007/BF01048016

Bolon, D.S. (1997). Organizational Citizenship Behavior among Hospital Employees: A Multidimensional Analysis Involving Job Satisfaction and Organizational Commitment. Hospital \& Health Services Administration, 42(2), pp. 221-241. Retrieved from https://pubmed.ncbi.nlm.nih.gov/10167456/

Buluc, B., \& Gunes, A. (2014). Relationship Between Organizational Justice and Organizational Commitment in Primary Schools. Anthropologist. 18(1), pp. 145-152. Retrieved from https://www.tandfonline.com/doi/abs/10.1080/09720073.2014.11891530

Chevalier,Tamghe. (2019). Organizational justice and organizational commitment of public secondary school teachers in Cameroon. Journal of Education and Practice, IISTE, 10 (36), 157-166. Retrieved from https://www.researchgate.net/publication/340522722_Organizational_Justice_and_Organizational_Com mitment_of_Public_Secondary_School_Teachers_in_Cameroon

Collquitt, A., Canlun, E., Wesson, J., \& Porter, C. (2001). Justice at the millennium: a meta-analysis review of 25 years of organizational justice research. Journal of Applied Psychology, 86(3), pp. 425- 445. Retrieved from https://www.researchgate.net/publication/11920237_Justice_at_the_Millennium_A_MetaAnalytic_Review_of_25_Years_of_Organizational_Justice_Research

Demir, K. (2016). Relations between teachers' organizational justice perceptions and organizational commitment and job satisfaction in the school: a meta-analysis. Educational Administration and Management Journal, 
Fathi Shamma, Reem Al-Zu'bi (2020). High diploma students' perceptions of justice and its correlation with organisational commitment.. Cypriot Journal of Educational Science. 15(4), 854 -869. DOI: 10.18844/cjes.v\%vi\%i.5064

$1(13)$.

Retrieved

from https://www.researchgate.net/publication/297680252_Relations between teachers'_organizational_just ice_perceptions_and_organizational_commitment_and_job_satisfaction_in_the_school_A_meta-analysis

Dodman, K., Rahim, M., \& Zadeh, N. (2014). Examining the relationship between perceived organizational justice and dimensions of organizational commitment. International Journal of Advanced Biological and Biomedical Research, 2(7), pp. 2319-2326. Retrieved from https://www.researchgate.net/publication/323443716_Examining_the_Correlation between_Organisational_Justice_and_Organizational_Commitment_with_Perceived_Organisational_Sup port_of_the_Malaysian_High_Performance_School_Sports_Developmental_Programme_SP

Edeh, O., \& Joy, U. (2019). Organizational justice and employee commitment of selected private secondary school teachers in Nigeria. International Journal of Management \& Entrepreneurship Research, 1(1), pp. 18-30. Retrieved from https://papers.ssrn.com/sol3/papers.cfm?abstract_id=3480813 (Accessed 11-1-2020).

Fahdawi, K., \& Al-Qatawneh, A. (2004). The effects of organizational justice on organizational loyalty: A field study of government departments in the southern governorates of Jordan. [Al-Majalah Alearabiat Lil'iidara], Amman, 24(2), pp. 1-52.

Goyker, N. (2018). Organizational commitment of high school teachers. Journal of Education and Training Studies, 6 (3), $\quad$ pp. 115- $125 . \quad$ Retrieved from https://www.researchgate.net/publication/324155199_Organizational_Commitment_of_High_School_Te achers

Greenberg, D. (1987). Organizational justice: yesterday, today, and tomorrow. Journal of Administration, (16), pp. 606-613. Retrieved from https://journals.sagepub.com/doi/abs/10.1177/014920639001600208

Hamid, S. S. (2003). The impact of the correlation of the individual on his leader and his understanding of organizational support as moderators on the correlation between organizational justice and the behavior of organizational citizenship: field study. [Majalat Al-Muhasabah wa Al'iidara wa Al-Ta'amin], 61(42), pp. 1-54.

Harris, K., J., Harvey, P., \& Kacmar, M. (2009). Do social stressors impact, everyone, equally? An examination of the moderating impact of core self- evaluations. Journal of Business and Psychology, 24, pp. 153-64. Retrieved from https://link.springer.com/article/10.1007/s10869-009-9096-2

Hassaani, R. (2015). Organizational justice and its correlation to organizational Commitment: A field study at the directorate of state ownership of Umm al-Bawqi's state. Master's Thesis. [Jamiet Umm Al-Baqi]. Retrieved from https://psycnet.apa.org/record/2003-01929-005

Imamoglu, Salih, Ince, H., Turkcan, H., \& Atakay, A. (2019). The effect of organizational justice and organizational commitment on knowledge sharing and firm performance. Procedia Computer Science, 158, pp. 899-906. https://doi.org/10.1016/j.procs.2019.09.129

Jameel, A., Mahmoud, Y., \& Swran, J. (2020). Organizational justice and organizational commitment among secondary school teachers. University-Erbil Journal of Humanities and Social Sciences, 4(1), pp. 1-6. Retrieved from https://papers.ssrn.com/sol3/papers.cfm?abstract_id=3525350

Jang, J., Lee, D., \& Kwon, G. (2019). An analysis of the Influence of organizational justice on organizational commitment. International Journal of Public Administration. DOI: 10.1080/01900692.2019.1672185.

Karanja, G., Gachunga, H., \& Kalio, A. (2014). Effects of distributive justice on organizational commitment of public secondary school teachers in Kenya. International Journal of Science and Research, 3(7), pp. 17911796.Retrieve from https://pdfs.semanticscholar.org/6718/300484cc750341635ba3c077e6923804faf7.pdf

Khalil, A., \& Sharaf, I. (2014). The impact of organizational justice on teachers' work-related outcomes in Egypt with an integer programming model. American Journal of Economics and Business Administration, 4(6), pp. 148-158. Retrieved from https://ideas.repec.org/a/abk/jajeba/ajebasp.2014.148.158.html 
Fathi Shamma, Reem Al-Zu'bi (2020). High diploma students' perceptions of justice and its correlation with organisational commitment.. Cypriot Journal of Educational Science. 15(4), 854 -869. DOI: 10.18844/cjes.v\%vi\%i.5064

Luo, Y. (2007). The Independent and Interactive Roles of Procedural, Distributive, and Interactional Justice in Strategic Alliances. The Academy of Management Journal, 50(3), 1-36. Retrieved from https://www.jstor.org/stable/20159877?seq=1

McFee, E. (2016). Teacher Perceptions of Organizational Justice and Title in School Status, Doctorate of Education. Grand Canyon University, ProQuest Dissertations Publishing, 10110895. Retrieved from https://search.proquest.com/openview/a571a6b4142c52b9a83a97838805808a/1.pdf?pqorigsite $=$ gscholar $\& \mathrm{cbl}=18750 \&$ diss $=\mathrm{y}$

Melhem, M., \& Al-Aqra, N. (2018). The level of organizational justice in Palestinian government Schools, paper presented at the sixth Joint International Scientific Conference, entitled: Developments in administrative and economic sciences in Jordan, and its role in improving level performance. Amman: Jordan. Retrieved from https://www.qou.edu/ar/viewCmsContentDtl.do?contentId=58491

Meyer, P., Allen, N., J., \& Smith, A. (1997). Commitment to organizations and occupations: extension and test of a three-component conceptualization. Journal of Applied Psychology, 78(4), pp. 538-552. DOI: 10.1037/0021-9010.78.4.538

Mowday, R., Steers, R., \& Porter, L. (1979). The measurement of organizational commitment. Journal of Vocational Behavior, 14, 224-247. Retrieved from https://doi.org/10.1016/0001-8791(79)90072-1

Petertomade, V. (2018). Analysis of teachers' commitment and dimensions of organizational commitment in Edo state public secondary schools. Journal of Education and Social Research, 8(3), 78-92. Retrieved from https://www.mcser.org/journal/index.php/jesr/article/view/1032

Rego, A., Chuna, M. (2010). Organizational justice and citizenship behaviors: study in the Portuguese cultural context. Applied Psychology, 59 (3), pp. 404-430. Retrieved from https://www.researchgate.net/publication/230169834_Organisational_Justice_and_Citizenship_Behavior s_A_Study_in_the_Portuguese_Cultural_Context

Reichers, A. (1985). A review and reconceptualization of organizational commitment. The Academy of Management Review, 10(3), 465-476. Retrieved from https://psycnet.apa.org/record/1986-02676-001 Accessed on 2-10-2019. $\quad$ Retrieved from https://www.researchgate.net/publication/314116303_An_Analysis_of_Organizational_Justice_and_Org a nizational_Identification_Relation_Based_on_Teachers'_Perceptions Accessed on 9-10-2019.

Safdar, S., \& Liu, L. (2019). The Influence of justice on the commitment of Pakistani bankers: Job satisfaction as a mediator. International Journal of Public Administration. DOI: 10.1080/01900692.2019.1668408.

Salehi, M., Sima, H., \& Fahimi, A. (2020). The relationship between organizational justice and auditors' professional skepticism with the moderating role of organizational commitment and identity. Curr Psychol. https://doi.org/10.1007/s12144-020-00700-9

Shamma, F. (2018). The level of organizational commitment among schoolteachers in the Arab Israeli schools from their point of view. European Journal of Educational Sciences, pp. 95-101. Retrieved from https://books.google.co.il/books?hl=en\&lr=\&id=0cNmDwAAQBAJ\&oi=fnd\&pg=PA103\&dq=info:qqU

FGZRX nKAJ:scholar.google.com\&ots=d3Mz5QdGWk\&sig=-MnAaGBaeS5hbw4kBZFp3Pj$\mathrm{u} 9 \mathrm{c} \& \mathrm{redir} \_\mathrm{esc}=\mathrm{y} \# \mathrm{v}=$ onepage \&q\&f$=$ false

Shamma, F., \& Al-Sharman, M. (2018). Organizational justice among school principals within the green line and its relationship with the organizational commitment of teachers from their point of view. Journal of Educational and Psychology Science, 7, pp. 695-728. Retrieved from https://www.ijsr.net/get_abstract.php?paper_id=ART2018468

Srinivasan, P., \& Selvi, K. (2016). Organizational commitment of higher secondary school teachers. American Journal of Educational Research, 4(5), pp. 404-407. Retrieved from http://www.sciepub.com/reference/238433 
Fathi Shamma, Reem Al-Zu'bi (2020). High diploma students' perceptions of justice and its correlation with organisational commitment.. Cypriot Journal of Educational Science. 15(4), 854 -869. DOI: 10.18844/cjes.v\%vi\%i.5064

Tepper, J., \& Taylor, E.C. (2003). Relationships among Supervisors and Subordinates' Procedural justice perceptions and organizational citizenship behaviors. Academy of Management Journal, 46(1), 97-105. Retrieved from https://psycnet.apa.org/record/2003-01929-005

Terzi, A., Dulker, A., Altin, F., Celik, F., Dalkiran, M., Yulcu, N., Tekin, S., \& Deniz, U. (2017). An analysis of organizational justice and organizational identification relation based on teachers' perception. Universal Journal of Educational Research, 5(3), pp. 488-495. Retrieved from https://www.researchgate.net/publication/314116303_An_Analysis_of_Organizational_Justice_and_Org anizational_Identification_Relation_Based_on_Teachers'_Perceptions

Thibaut, W., \& Walker, L. (1975). Procedural Justice: A Psychological Analysis. Hillsdale: Lawrence Erlbaum Associates.

Retrieved

from https://www.scirp.org/(S(i43dyn45teexjx455qlt3d2q))/reference/ReferencesPapers.aspx?ReferenceID=16 56023

Till, R., Karren, R. (2011). Organizational justice and pay Level satisfaction. Journal of Managerial Psychology, 26(1), pp. 42-57. Retrieved from https://psycnet.apa.org/record/2011-01581-003

Ting, C. (2014). Organizational justice influences foci commitment of teachers via trust. International Journal of Learning Teaching and Educational Research, 7(1), pp. 78-92. Retrieved from https://www.semanticscholar.org/paper/Organizational-Justice-Influences-Foci-CommitmentTing/6389adc1cc7bd6d1eb378ef4f925abf0a1ea9296 
Fathi Shamma, Reem Al-Zu'bi (2020). High diploma students' perceptions of justice and its correlation with organisational commitment.. Cypriot Journal of Educational Science. 15(4), 854 -869. DOI: 10.18844/cjes.v\%vi\%i.5064

\section{Appendix A}

\section{Study Questionnaire}

\section{Dear respondent:}

We are conducting research to investigate the perceived level of organisational justice exhibited by principals of Jordanian schools and its relationship with the organisational commitment of teachers. Obtaining feedback from high diploma students who are also working as teachers is therefore vital for this research. Please assist by completing this survey; we appreciate you taking the time to complete it. Do NOT write your names on this questionnaire. If there are items you do not feel comfortable answering, please skip them. Your responses are voluntary and confidential and will not be identified by other individuals. Thank you for your cooperation. Your assistance is greatly appreciated. 